\title{
長野市松代地域における炭酸ガスの湧出量と地殼変動
}

\author{
北陽建設株式会社 長野営業所* 清 水 直 哉 \\ 信州大学理学部物質循環学教室** 塚 原 弘 昭 \\ 気像庁精密地震観測室 $* * *$ 古 舘 友 通 \\ 防災科学技術研究所**** 吉 田 則 夫
}

\section{Discharge of Carbon Dioxide and Crustal Movement at the Matsushiro Area, Nagano City}

\author{
Naoya Shimizu \\ Hokuyou Construction Co., Ltd., Nagano, Inaba 1993-1, Nagano 380-0912, Japan \\ Hiroaki TsukAHARA \\ Department of Environmental Sciences, Faculty of Science, Shinshu University, \\ Asahi 3-1-1, Matsumoto 390-8621, Japan \\ Tomomichi Furudate \\ Matsushiro Seismological Observatory of Japan Meteorological Agency, \\ Nishijo 3511, Matsushiro-machi, Nagano 381-1232, Japan \\ Norio Yoshida \\ National Research Institute for Earth Science and Disaster Prevention, \\ Tennodai 3-1, Tsukuba 305-0006, Japan
}

(Received April 21, 1997; Accepted January 14, 1998)

\begin{abstract}
Large amount of underground water with $\mathrm{CO}_{2}$ gas bubbles had flowed out from many spots for the period of the Matsushiro Earthquake Swarm, 1965-1967. Some of the springs are still alive. We explored possibility for detecting crustal activity, such as crustal deformation and seismicity by observing $\mathrm{CO}_{2}$ concentration in soil gas in the Matsushiro area. We measured $\mathrm{CO}_{2}$ concentration in soil gas once a week for 6 months at many places in two areas: (1) a fault zone of the Matsushiro Earthquake Swarm, and (2) floor of the tunnel of Matsushiro Seismological Observatory which is about $2.5 \mathrm{~km}$ away from the fault zone. The measurement points are located at various geological conditions. Remarkable high concentration of $\mathrm{CO}_{2}$ in soil gas was detected at measurement points in the fault zone. In particular, high concentration of $\mathrm{CO}_{2}$ was observed at a point on a fault. In contrast, on tunnel floor, out of the fault zone, the concentration is relatively low. Temporal variation, records of $\mathrm{CO}_{2}$ concentration of all measurement points, however, resemble one another in variation pattern. This suggests that the $\mathrm{CO}_{2}$ discharge is controlled by some wide regional scale mechanism. The pattern of the concentration variation is compared with those of seismic data, crustal strain data and meteorological data observed at the observatory. Good correlation is found between temporal variation in $\mathrm{CO}_{2}$ concentration and that in crustal strain observed with north-south orientation strainmeter, that is, $\mathrm{CO}_{2}$ concentration increase with expansion of the NS70-100 component of strainmeter. We propose a model of the variation in $\mathrm{CO}_{2}$ discharge in relation to crustal strain and fracture distribution. The strainmeter data shows that the crustal strain is largely influenced by rainfall at the Matsushiro area, for example, NS70-100 component of strainmeter expands after
\end{abstract}

* 干380-0912 長野市大字稲葉 1993-1

** 个390-8621 松本市旭 3-1-1 $\begin{aligned} & * * * \text { 厂 } 381-1232 \text { 長野市松代町西条 } 3511 \\ & * * * * \text { 厂305-0006 茨城県つくば市天王台 3-1 }\end{aligned}$ 
rainfall. Since many fractures having nearly the east-west direction are observed on the surface in this area, expansion in the north-south direction is expected after rainfall. Some pre-existing cracks will open with the expansion of neighboring cracks caused by water absorption. Since large amount of $\mathrm{CO}_{2}$ gas presents under this area, $\mathrm{CO}_{2}$ discharge rate increase with increase of width of passages. We can detect strain change of the fracture zone by $\mathrm{CO}_{2}$ monitoring.

Key words: Soil gas, $\mathrm{CO}_{2}$ discharge, Soil gas and crustal activity.

\section{§1. はじめに}

断層直上の土壌には, 炭酸ガス・ヘリウム・ラドン・ 水素ガスが，一般の土壌に比べ多く含まれていることが 知られている. 長野市松代地域であ, 群発地震時 (1965～1967) に土壌ガス中の炭酸ガス濃度の探査が行

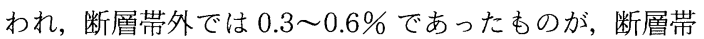
内では 5〜13\%にまで上昇することが報告されている [永田・伊䡕 (1969)]. この地域では, 地下深部起源の地 下水の湧出に伴って気泡状の炭酸ガスが, 群発地震の際 多量に放出され，現在も何力所かでそれが継続してい

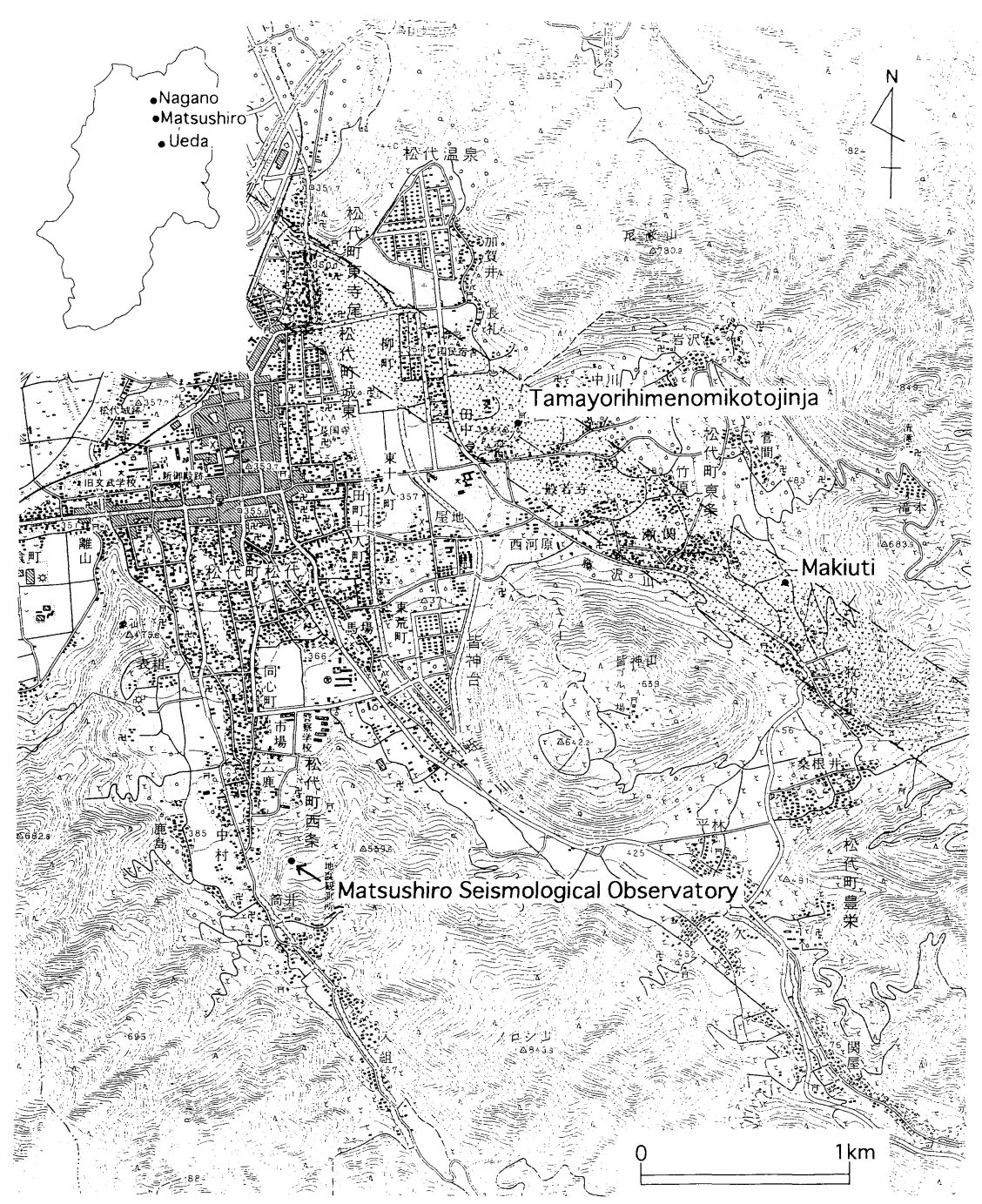

Fig. 1. Gas sampling sites in the Matsushiro area (solid circles). Dotted area corresponds to the left-lateral fissures area which were formed by the Matsushiro earthquake [TsunEIsHi and NAKAMura (1970)]. (Geographic map: from Geographical Survey Institute, 1/25000) 
る.したがって, 長野市松代地域で検出される炭酸ガス は, この地域の地款変動や地震活動と関連して増減する 可能性が高いと予想される.

以上のような見地から，松代地域で 1995 年 6 月〜 12 月の 6 カ月間, 土壌ガスを毎週一回サンプリングし，土 壌ガス中の炭酸ガス濃度の変動を調べた．得られた測定 結果を降雨, 気温・気圧変化などの気象変動及び松代の 気象庁地震観測室大坑道内に設置されている石英管伸縮 計により得られる地殻変動記録と比較しながら考察した W.

\section{§2. 測定地域}

\section{1 測定地域の概要}

1965 年に開始した松代地域及びその周辺直下を震源 とした松代群発地震の際, 地震断層が皆神山（みなかみ やま）北東部を中心に東西走向に近い割れ目からなる主 として北西・南東走向, 一部北東・南西走向の地割れ群 となって現れた [TSUNEISHI and NAKAMURA (1970)]. 今回, 土裹ガスの採取を行った地点は, Fig. 1 に示すよ うに，そのような地割れ群の直上あるいはその延長上に 位置する点之, 松代の気象庁地震観測室大坑道内（地割 れ群からは約 $2.5 \mathrm{~km}$ 離れている）である. 測定点の詳 細を以下に述べる.

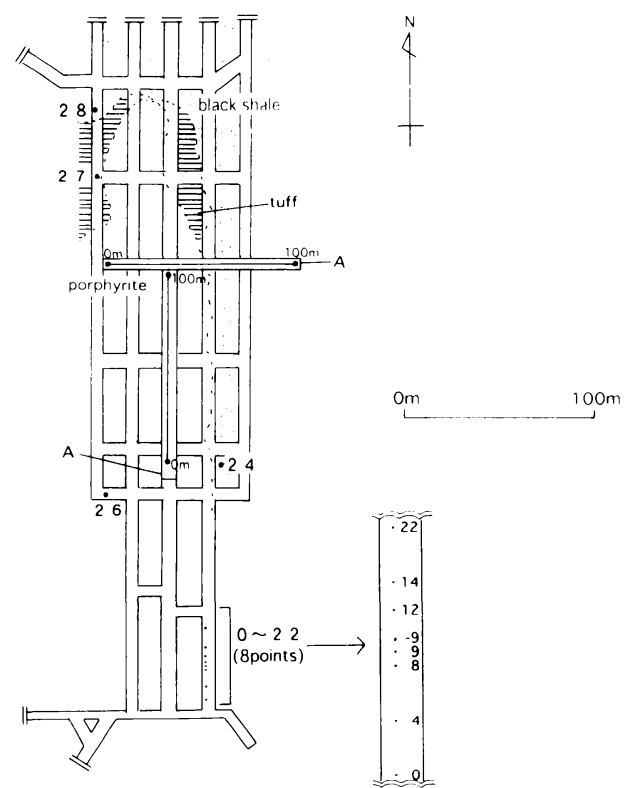

Fig. 2. Gas sampling sites in tunnel (solid circles with numbers from 0 to 28). A: Silica tube strainmeters and water tube tiltmeters. (geological map after NAGUmo et al., 1967)

\section{2 測定点}

\section{(1) 気象庁の地震観測室大坑道内}

Fig. 2 に示すように, 坑道内はひん岩と黒色頁岩から 構成されており, 境界付近には, 部分的に薄い凝灰岩の 層がある [南雲・他 (1967)]．観測ポイント 0, 4, 8, 9, $-9,12,14,22,26$ は, ひん岩の岩盤上にあり, 24, 28 は 黒色頁岩, 27 は凝灰岩の上にある. 坑道内は何枚かのド アで外気と隔離されており外気の影響を受けにくいた め, ガスの採取深度はとくに深くはせず， $10 \mathrm{~cm}$ であ る.ただし, 採取深度の違いによるガス成分・濃度の違 いを見るために設けた地点番号 -9 は, 深さ $35 \mathrm{~cm}$ であ る.

（2）玉依比売命神社（たまよりひめのみことじんじゃ） 玉依比売命神社付近は，基盤は泥岩とそれを貫くひん 岩で，その上を表土が薄くおおっている [松田 (1967)]. 観測ポイントは，薄い土壌におおわれた山の斜面にあ り, 松代群発地震時に地震断層直上に生じた地割れの延 長上にあたる，ガス採取は，採取深度の違いによる成 分・濃度の違いを見るために, $20 \mathrm{~cm}, 60 \mathrm{~cm}$ の 2 種類 の深さで行った．以降，それぞれ測定点名を神社浅部， 神社深部之記す。

(3) 牧内地区

牧内付近は, 主に沖積層より成る [森本・他(1966)]. 観測ポイントは畑の中にあり，断層直上での炭酸ガス濃 度の違いを確かめるために, 群発地震時の地表地震断層 の変位の認められる地点（石垣の並びが約 $10 \mathrm{~cm}$ くい 違っている）と，そこから約 $10 \mathrm{~m}$ 離れた地点で, 同じ 深さ $(40 \mathrm{~cm})$ からガス採取を行った，以降それぞれ，牧 内 1 , 牧内 2 と記す。

\section{§3. ガスの採取方法及び測定法}

\section{1 採取法}

（1）気象庁地震観測室大坑道内および玉依比売命神社 気象庁地震観測室大坑道内および玉依比壳命神社に は，Fig. 3(a)のようなガスの採取装置を設置した。この 装置では，地下から湧出してきたガスはプラスチック製 のじょうご（直径 $12 \mathrm{~cm}$ ）内に集まる. ビニールパイプ 上端は折り曲げられ，ビニールテープでゆるめに巻かれ ており，新たにガスが地下から供給されたときには，ビ ニールパイプ内のガスは, ビニールパイプを介して空気 中に放出され，新しいガスとの置換が円滑に行われるよ うにしている.

このような装置から, シリンジ（注射器）を用いてビ ニールパイプからガスを $12 \mathrm{~m} l$ 採取する. そのガスをあ らかじめ真空にしておいたゴム栓付き試験管（容量 8 $\mathrm{m} l$ ) 内にゴム栓からシリンジで圧入し, 実験室に持ち帰 


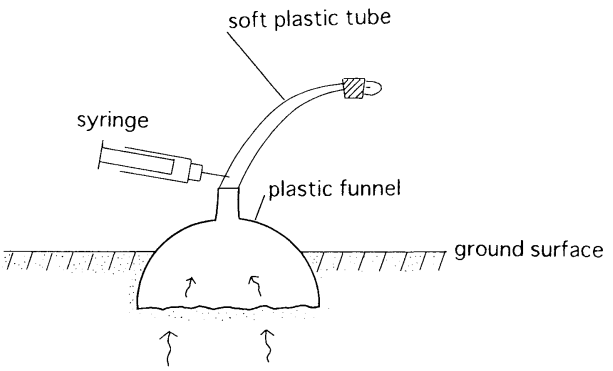

(a)

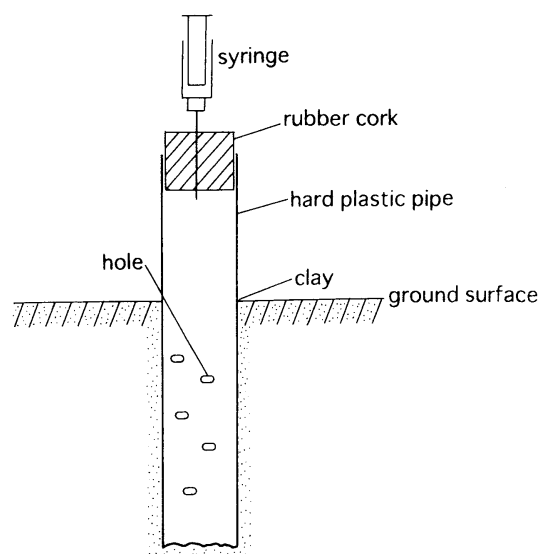

(b)

Fig. 3. Soil gas sampling methods.

(a): for measurement points in tunnel and at Tamayorihimenomikotojinja; (b): for measurement points at Makiuti.
る。これを通常一週間に一回実施した。なお，運搬中に 試験管内への外気の流入がないよう，栓に用いているシ リコン栓の上部, 側部にビニールテープで補強を行っ た.

(2) 牧内地区

牧内では，Fig. 3(b) のような装置を設置した.この装 置は, 設置予定地面にまずステンレスパイプを打ち込 み,できた孔に塩ビパイプ（内径 $2 \mathrm{~cm}$, 側面に数力所穴 があいている）を差し込んだあので, 孔と塩ビパイプと の隙間を粘土などでふさいでいる.

設置直後, 塩ビ管の中をより早く土壌ガスで置換させ るために，塩ビパイプ上端をゴム栓でふたをした後，塩 ビ管に残っている空気をシリンジで吸い出した。なお, ガスの置換時間を考慮し, 試料ガス採取はこの装置の設 置一週間後から行った。

\section{2 測定法}

採取したガスは，採取の当日または翌日に，固定相に シリカゲル，移動相に酸素ガスを用いた TCD 型ガスク ロマトグラフ（大倉ガスクロマトグラフ Model-802T) により分析を行った．このガスクロマトグラフで, $\mathrm{N}_{2}$, $\mathrm{CO}_{2}, \mathrm{CH}_{4}$ はクリアに分離されており, 各気体の濃度 は, 標準ガスから検量線を作成し, それにより決定した。

\section{§4. 観測結果及び考察}

\section{1 観測結果の概要}

$\mathrm{N}_{2}, \mathrm{CH}_{4}$ には, $\mathrm{CO}_{2}$ と比べて目立った時間変動がない. また, 前述のように, この地域は, 炭酸ガスの湧出が地 殻変動・地震活動と関係が強いと予想されるので, 以下

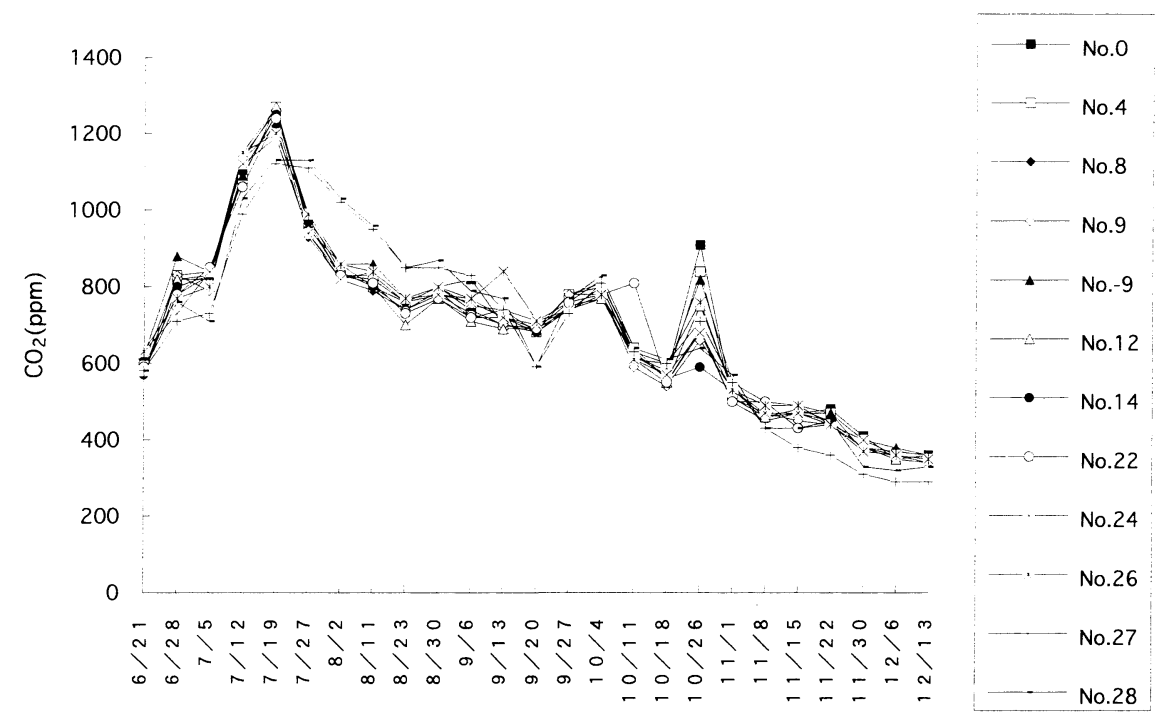

Fig. 4. Temporal variation in $\mathrm{CO}_{2}$ concentration of soil gas from the observation points in tunnel. 
では, 炭酸ガス濃度の観測データについてのみ議論す る.

Fig. 4 に, 地震観測室大坑道内の全採取ポイントの炭 酸ガス濃度の時間変動を示す. 27 と 28 が他の測定点と 比べて多少異なった濃度を示すが，すべてのデー夕が, 数 $100 \mathrm{ppm}$ から $1300 \mathrm{ppm}$ の間におさまっており，経 時変化もほとんど同じパターンを示している. 採取ポイ ントは地震観測室大坑道内のほぼ全域にわたっているの で, 坑道内での地下からの炭酸ガスの放出は, 何らかの 広域の変動に支配されて変動しているのではないかと推 定される.

次に, 地震観測室大坑道内のデータと他の地点のデー 夕とを比較してみる. Fig. 5 に, 地震観測室大坑道内, 玉依比売命神社, 牧内地区における炭酸ガス濃度の変動
を示す.なお, 地震観測室大坑道内では, Fig. 4 のよう に, 全採取ポイント間で濃度・成分の変動に大きな違い は見られないので，この図では 12 ある採取ポイントの 平均值を示す. Fig. 5 の 3 枚のグラフの縦軸の数值の違 いから，観測場所毎に濃度の絶対量に大きな違いのある ことが分かる.すなわち, 坑道内では数 $100 \mathrm{ppm} \sim$ $1300 \mathrm{ppm}$ であるが, 神社では数\%にまでなっている. また各観測点での採取ポイント間の炭酸ガス濃度を比較 してみると, 玉依比売命神社では, 深所ほど炭酸ガス濃 度が高いことや, 牧内地区では, 断層線上と推定される ポイント（牧内 1）の方が，炭酸ガス濃度が高いことが 示されている.

さらに, Fig. 5 から, 炭酸ガス濃度はいずれの場所で 6観測期間を通じて時間と共に大きく変動していること
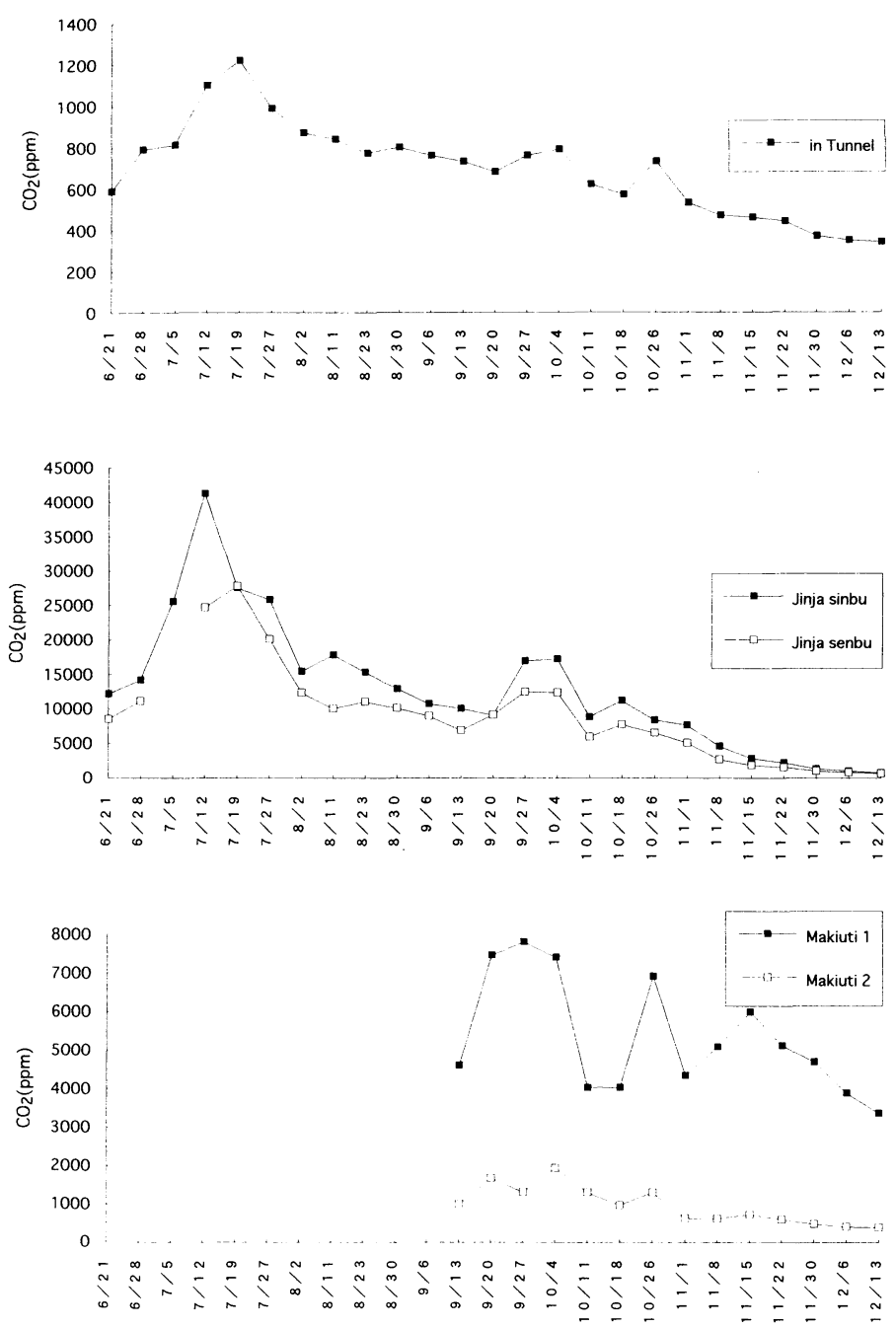

Fig. 5. Temporal variation in $\mathrm{CO}_{2}$ concentration of soil gas. The top shows average concentration observed at 12 points in the tunnel. 
あ分かる.この濃度の変動パターンには, 類似性が見ら れる. とくに, 地震観測室大坑道内之玉依比売命神社の 濃度の变動パターンはよく似ており, 夏季に高く, 冬季 に低い傾向や， 7 月 5 日前後から始まる急激な濃度増加 あ確認できる．これは，地震観測室大坑道内，玉依比売 命神社という採取条件が明らかに異なる互いに離れた (距離約 $2.5 \mathrm{~km}$ ) 2 地点の炭酸ガス濃度の変動が同じ要 因によって引き起こされていることを示唆している.

そこで, この要因を気象変化や地殸変動に求め, 降雨 や気温・気圧变化や, 歪み变化との関連を調べてみる. なお，測定期間が 1 年に満たないので, 測定デー夕は短 期的变動についてのみ考察する.

\section{2 気温・気圧との関係}

すでに述べたように，地震観測室大坑道内と玉依比売 命神社に打ける炭酸ガス濃度は, 夏季に高く, 冬季に低 い傾向が見られる，そのため，この炭酸ガスは，夏季の 地表面の蒸発散の活発化あるいは生物活動の活発化によ り湧出してくるような比較的浅部を起源とするものであ る可能性もある. しかし, この年の気温は, 7 月よりあ 8 月の方が高いにもかかわらず，今回観測された炭酸ガス 濃度は 8 月になって下がっており, 牧内地区において は, 10 月半ばから 12 月にかけて, 気温変化のような単 調な濃度低下が認められない。 また, 坑道内が生物活動 の活発な地表から遠く離れており, 測定点の温度も年間 を通じてほぼ一定（変動幅は $1^{\circ} \mathrm{C}$ 以内）であることを考 慮すると, 土壌ガス中の炭酸ガス濃度の変動は, 気温の 上下動が主要な原因ではないと考えられる。

そこで, 次に, 気圧との関係を調べた，気圧の日変化 幅は大きいので, 移動平均をとって炭酸ガス濃度と比較 した. ぞれを Fig. 6 に示す. 気圧変化には, 炭酸ガス濃
度变化と無関係に見えるピークが多く見られ，7月に最 大となるピークを持つ濃度変化との相関は明確ではな い.

気圧変化が，炭酸ガスの湧出量に影響を与える原因と して考えられる機構は, 気圧変化による地中の亀裂の開 閉に伴う湧出量の増減, 地下水中の炭酸ガスの溶解度の 変化に伴う湧出量の増減, 地中の気圧と大気圧の差に伴 う気体の上下移動による湧出量の増減が挙げられる。こ れらの現象では，いずれあ気圧が低い時に湧出量が増加 すると考えられる。そそこで, 気圧が低くなるピーク時の 炭酸ガス濃度に注目してみた。濃度が最高となる 7 月 19 日のピーク時に気圧が低下していることが分かる. しかし，このような関係は他のピーク時にはほとんど見 られない．また，逆に気圧が高くなるピーク時に濃度が 低くなっているわけでもない。したがって，炭酸がス濃 度の増滅が気圧変化によるものであるとは考元にくい． なお，玉依比売命神社，牧内地区における炭酸ガス濃度 変化と気圧変化も比較してみたが，はっきりした関係は 見られなかった。

\section{3 降雨との関係}

降雨が地中に浸透することにより, 地下水位が上昇し て炭酸ガス主成分の地中ガスが追い出され，炭酸ガス濃 度が上昇することがある. 実際, 测定データと降雨とを 比較すると, 降雨の多い時期に炭酸ガス濃度のピークが ある. しかし, 次の事実は, 炭酸ガス濃度の増加の主な 原因は，降雨の浸透のための地下水位上昇による地中ガ スの放出ではないことを示していると考えられる.

炭酸ガス濃度の測定点は, Fig. 2 のように坑道内に広 く分布している．その中には降雨がなくとも湿った状態 の所や降雨時直後だけ水が浸出してくる所もある．例え

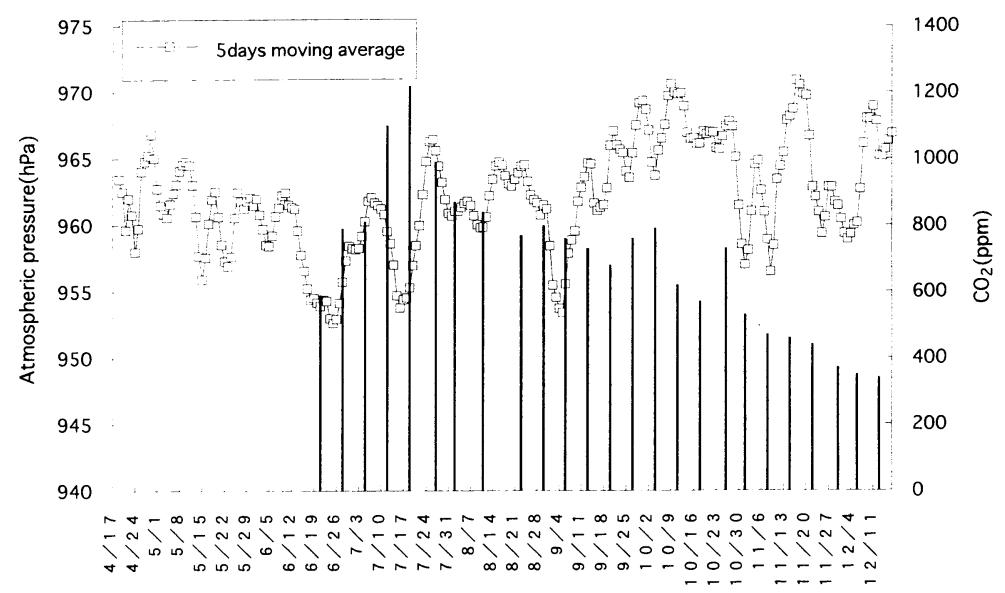

Fig. 6. Temporal variation in atmospheric pressure (5 days moving average) and $\mathrm{CO}_{2}$ concentration (solid lines) observed in tunnel. 
ば，測定点 26 近くの難透水性の岩盤中に掘削されてい るボーリング孔の観測期間中の地下水位（気象庁地震観 測室記録）は，非常に緩慢でなめらかな変化曲線を描い て 4 月から 8 月下旬まで単調に上昇しており，降雨によ る直接的変動は見られない. 4 月から水位の高い 8 月 末〜 10 月半ばまでの水位変化は約 $1.4 \mathrm{~m}$ である.この ように降雨による地下水位の变化は, 坑道内でも場所に よって大きく異なっている可能性がある.

そのような状態の違いにも関わらず，Fig. 4 に示され るように, 炭酸ガス濃度は全測点で類似した変動をして おり, 濃度の絶対值もほぼ等しい. これは, 坑道内の炭 酸ガス濃度の変動の主要な原因が降水の浸透による地下 水位の上昇ではないことを示している.

\section{4 石英管伸縮計の記録との関係}

地震観測室大坑道内には, 全長 $100 \mathrm{~m}$ の石英管伸縮 計が南北方向と東西方向にそれぞれ設置されており, 石 英管の端 (0 m 地点) を固定点として, 石英管上の $30 \mathrm{~m}$, $70 \mathrm{~m}, 100 \mathrm{~m}$ 地点で石英管を基準として岩盤の伸縮の測 定が行われている. Fig. 7 に，石英管伸縮計より得られ た 1995 年 4 月 17 日〜 12 月 17 日の南北成分と東西成 分の各区間すなわち, $0 \mathrm{~m}-30 \mathrm{~m}$ 間, $30 \mathrm{~m}-70 \mathrm{~m}$ 間, 70 $\mathrm{m}-100 \mathrm{~m}$ 間の歪み変化を示す。 また歪みに大きな影響 を及ぼすとされる日積算雨量についても同図に示す.

Fig. 7 において，NS0-30 は， $0 \mathrm{~m}-30 \mathrm{~m}$ の歪み（以後 STNS0-30 と表す), NS30-70 は, 南北成分の $30 \mathrm{~m}$ 地 点と $70 \mathrm{~m}$ 地点の間の長さ $40 \mathrm{~m}$ の区間の歪み (STNS 30-70) を示している. また，EW0-30などあ同様の表 現である (STEW0-30). なお，東西成分の $100 \mathrm{~m}$ 地点 での測定值 EW 100 は, 測定機器の故障により正確な值 が得られていないため，EW70-100は除いてある.

歪みと降雨との関連性が非常に高いことがこの図から 分かるが，降雨については $4 \cdot 5$ 節で述べることにし，こ こでは歪み変化と炭酸ガス濃度変化との関連についてみ ていくことにする. Fig. 7 を見ると, 南北成分では, 歪 み変動の大きな時期は 3 区間とも同期しているように 見えるが，その変動の向きや量は異なっている，一方，
東西成分についてはそのような違いは見えない，

そこで，どの区間の歪み変化と炭酸ガス濃度とが最も 関連が深いのかを調べるために，地震観測室大坑道内， 玉依比売命神社, 牧内地区における炭酸ガス濃度と各区 間の歪みとの相関係数を求め, Table 1 に示す. 歪みを 測定しているのは坑道内であるので，まず坑道内の炭酸

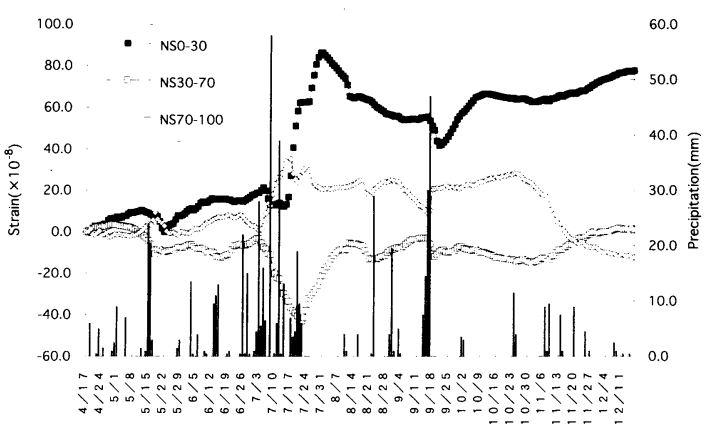

NS component

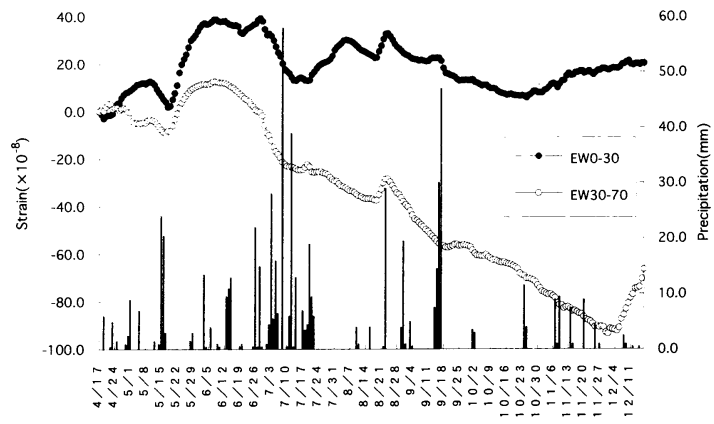

EW component

Fig. 7. Temporal variation in crustal strain and daily precipitation. NS0-30, NS30-70, and NS70-100: crustal strain between $0 \mathrm{~m}$ and $30 \mathrm{~m}, 30 \mathrm{~m}$ and $70 \mathrm{~m}$, and $70 \mathrm{~m}$ and $100 \mathrm{~m}$ along NS strainmeter, respectively. EW0-30 and EW30-70: crustal strain between $0 \mathrm{~m}$ and $30 \mathrm{~m}$, and $30 \mathrm{~m}$ and $70 \mathrm{~m}$ along EW strainmeter, respectively. Solid lines: daily precipitation. (Data from Matsushiro Seismological Observatory of Japan Meteorological Agency.)

Table 1. Correlation coefficients between strain variation and $\mathrm{CO}_{2}$ concentration variation with time for the period from June, 1995 to December, 1995.

\begin{tabular}{lrrrrr}
\hline \hline & in Tunnel & Jinja sinbu & Jinja senbu & Makiuti 1 & Makiuti 2 \\
\hline NSO-30 & -0.36 & -0.51 & -0.40 & -0.72 & -0.70 \\
NS30-70 & -0.76 & -0.68 & -0.83 & -0.39 & -0.45 \\
NS70-100 & 0.67 & 0.54 & 0.61 & 0.45 & 0.73 \\
EW0-30 & 0.16 & 0.13 & 0.08 & -0.20 & -0.35 \\
EW30-70 & 0.72 & 0.71 & 0.70 & 0.40 & 0.77 \\
\hline
\end{tabular}


ガス濃度変化との相関を見てみる. 測定值は, 坑道内 12 測点の平均値を用いた. Table 1 から, 南北成分では 30 $\mathrm{m}-70 \mathrm{~m}$ 間と $70 \mathrm{~m}-100 \mathrm{~m}$ 間, 東西成分では $30 \mathrm{~m}-70$ $\mathrm{m}$ 間の歪みとの相関の高いことが分かる. その中で STEW 30-70 は, 炭酸ガス濃度変化の特徴を示す 7 月 の大きな変化に対応するピークが見られない.

相関が高く, 7 月に特徵的な変動をした南北成分の 30 $\mathrm{m}-70 \mathrm{~m}$ 間と $70 \mathrm{~m}-100 \mathrm{~m}$ 間の歪み変化と炭酸ガス濃 度について検討してみる. 物理的因果関係のあるのがど ちらかについては, 相関係数の值だけでは優劣がつけら れないので，それぞれのデー夕の特徴のある変動をあう 少し詳しく見てみる.Fig. 8(a)·(b) は，炭酸ガス濃度変 化と歪み変化との間に時間差があるかどうかを比べたグ ラフである. 最大のピーク時期を比べると, Fig. 8(a) か ら，STNS30-70 の歪み変化のピークの方が炭酸ガス濃
度のピークより遅れていることが分かる. 一方, Fig. 8 (b) からは, 逆に, STNS70-100 の歪み変化のピークの 方が先行していることが分かる. 歪み变化と炭酸ガス濃 度の間に因果関係があるとしたら, 歪み変化が原因で炭 酸ガス濃度が変化するのであって，決してその逆ではな い．また共通の原因で歪み変化と炭酸ガスの湧出とが制 御されているとすれば, 物質の移動現象である炭酸ガス の涌出には遅れが伴う．いずれにしても, 歪み変化が先 行するはずである．このことを考慮に入れると，物理的 因果関係から意味のあるのは, 歪み变化が炭酸ガス濃度 变化に先行した STNS70-100 の示す歪み変化である. つまり南北方向に地殼が伸張して，その後炭酸ガス濃度 が増加するというあのである. 一方, 坑道内以外の測定 点で得られた炭酸ガス濃度変化は, Fig. 5 に示されるよ うに坑道内で測定された濃度変化と非常によく似た変動

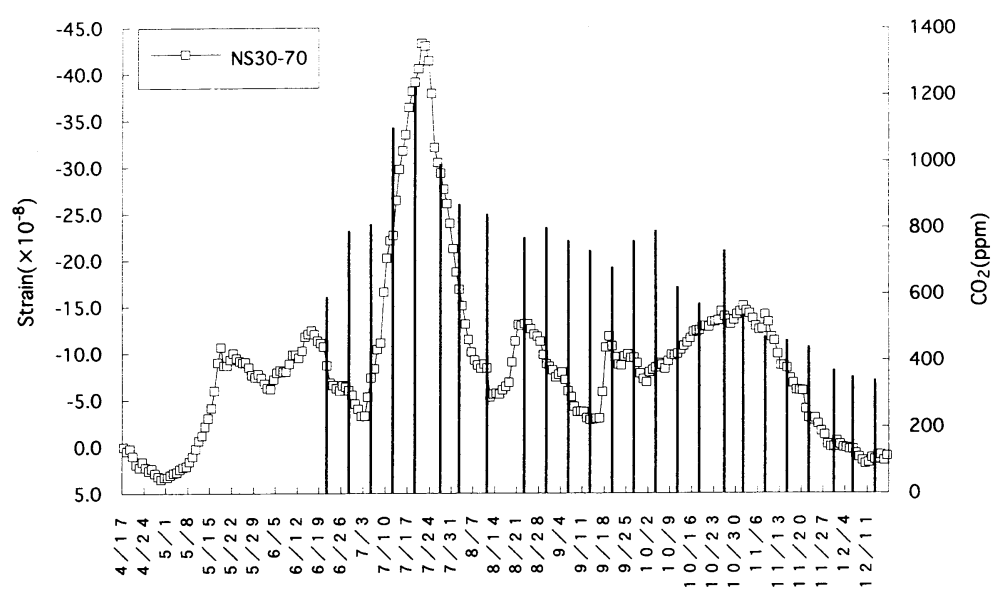

(a)

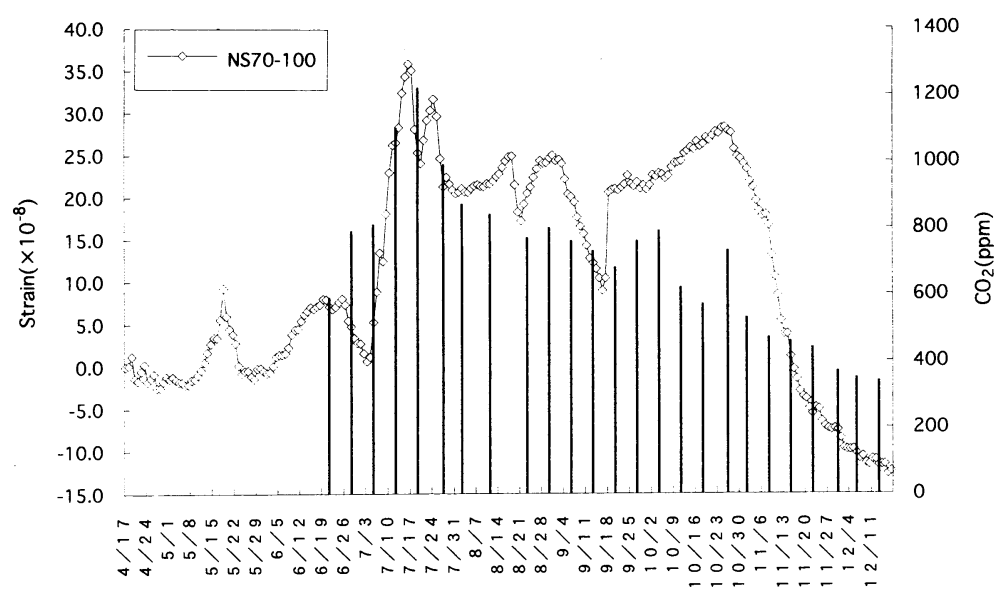

(b)

Fig. 8. Temporal variation in crustal strain and $\mathrm{CO}_{2}$ concentration (solid lines) observed in tunnel. (a) STNS30-70 (square). (b) STNS70-100 (diamond). 
を示すため相関係数は高いが，ピーク時間は必ずしも一 致しておらず, 場所により数日の時間差があることが分 かる.

\section{5 歪みと雨量}

炭酸ガス濃度変化も歪み変化も 7 月前後に大きな変 化を示している.この時期は降雨の多かった時期であ る.そこで，石英管伸縮計の南北成分の各区間の降雨時 の動きに注目してみる.

西前・涌井 (1996) は, 松代の地震観測室大坑道内の 歪みデータと降雨との関係について次のように述べてい る. 松代ではある程度以上の量の降雨があると, その影 響が南北歪みの伸縮変化に現れる. まず, 縮み変化が現 れて数日後にピークを持ち, その後, 降雨期間中の積算 雨量に比例した伸び変化が現れてくる. 西前・涌井 (1996) のこの記述は, 全長 $100 \mathrm{~m}$ の石英管伸縮計の伸 縮と降雨について述べたあのである. $100 \mathrm{~m}$ を 3 区分 し，それぞれの区間の伸縮と降雨量をグラフにしたもの がFig. 7 であるが, これを見ると, STNS0-30 と STNS 30-70 は STNS70-100 と逆の動きをする傾向のあるこ とが分かる.すなわち, STNS0-30 と STNS30-70 が降 雨後にまず縮み変化を示すのに対し, STNS70-100は 伸び変化を示している．降雨量の少ない時に，必ずしも 同様の変化が現れるとは限らないが， 7 月だけでなく 9 月中旬の $40 \mathrm{~mm} / \mathrm{day}$ を越える降雨時にも, STNS0-30 とSTNS30-70 の縮み変化に対して, STNS70-100の 伸び変化が確認できる.

これらの観測事実は次のように理解できる. $70 \mathrm{~m}-$ $100 \mathrm{~m}$ 間は, 降雨量の多い時に水を蓄えて伸張する区間 であるため, 周辺を圧迫して， $0 \mathrm{~m}-30 \mathrm{~m}$ 間及び $30 \mathrm{~m}-$ $70 \mathrm{~m}$ 間を収縮させる. $0 \mathrm{~m}-30 \mathrm{~m}$ 間, $30 \mathrm{~m}-70 \mathrm{~m}$, 70 m-100 m の地質はいずれも同時代のひん岩で構成さ れている (Fig. 2) ことから, 70m-100 m 間には $0 \mathrm{~m}-30$ $\mathrm{m}$ 間之 $30 \mathrm{~m}-70 \mathrm{~m}$ 間に比べ早期に水を吸収しやすい比 較的大きな割れ目群が存在しており，この割れ目群が降 雨時に水を吸収して，70 m-100 m 間が南北方向に伸張 するのであろう.

松代地域のひん岩中には, ひん岩貫入後の中新世後 期〜鮮新世前期に形成されたと考えられる節理を主体と した東西走向に近い割れ目系が顕著に発達している［村 井(1967)]. 歪み計の NS 成分の 70 m-100 m 間の地下 に, そのような走向の割れ目群のうち, 降雨により膨張 しやすいむのが存在していたのではないかと考えられ る.なお，小さな伸縮変化は降雨時以外にも認められる が，その原因は不明である。

\section{6 土壤ガス中の炭酸ガス濃度の変化機構}

以上のことを踏まえ, 岩盤の歪み変化に伴って高濃度
の炭酸ガスを含む地下深部のガス湧出量に変化が生じる 機構を以下に提案する. なお, 歪み測定が行われていな かった玉依比売命神社と牧内地区において，地震観測室 大坑道内の南北歪みの变化による湧出機構がそのまま適 用できるかよ゙うかは不明であるが，同様の機構による可 能性は高いと思われる.

松代地域には，炭酸ガスを気泡として含む深層起源と 思われる湧水 [中村 (1971)] が, 群発地震時に発生し, 今なお多くの場所で見られることから，地下に炭酸ガス 源が存在すると考えられる。したがって, 歪みとの関連 を考えるとき, 歪み变化によって炭酸ガスが新たに生成 されるとか間隙に少量存在していたものが絞り出される などのメカニズムではなく, 常時地下から放出されてい るガスが, 歪み変化による割れ目の開閉によって放出が 容易になったり困難になったりすることが主要な要因で あると考えるのが妥当である.

今回, 南北伸張の歪み変化により炭酸ガスの湧出量が 増加するモデルが必要とされる.すなわち Fig. 9 に示す ように，観測点付近に南北伸張（圧縮）により開口（閉 口）するような東西走向に近い割れ目群が存在していた とするモデルである．つまり，水を吸収しやすい比較的 大きな割れ目がほぼ東西に多数走っており（Fig. 9 の B 地域), 降雨時に水を蓄え地面が南北方向に伸張するの である。この時，均質に割れ目があり，かつ同量だけ水

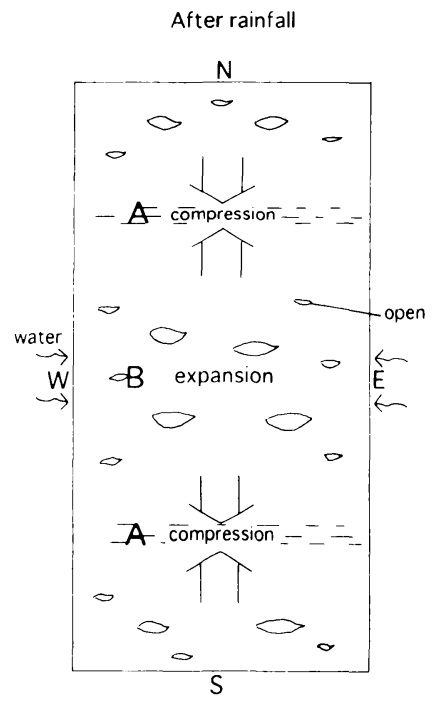

Fig. 9. Schematic drawing of a model. Region B expands with water saturation of preexisting cracks after rainfall. Some dry closed cracks in the region $\mathrm{B}$ are expected to open accompanying with the expansion. $\mathrm{CO}_{2}$ gas discharge increases due to the dry open cracks in the region $\mathrm{B}$. 
が浸透すれば, 岩盤自体としては均等に膨張するはずで ある. しかし，実際の岩盤は割れ目の分布は不均質で， 透水性も一様ではなく，降雨を受ける地形にも凹凸があ るので，水の浸透による膨張現象は岩盤中で三次元的に 不均等に進行する，そのため，水が浸入していない岩盤 あ変形を受け, 既存亀裂があれば開（閉）口するものあ でてくる.Fig. 9 の B 地域のような伸張地域では, 水の 浸透がなければ開口するものが増えると考えられる，炭 酸ガスは,この開口された割れ目を通って地表に湧出し てきていたのではないだろうか. なお，降雨が続けば, これらの開口割れ目の中には水で満たされるあのもでて くるが, 同時に, 歪みがさらに進行して別の開口割れ目 が出現することも考えられる。また坑道内での炭酸ガス 濃度が, 観測点（最大約 $300 \mathrm{~m}$ 離れている）によらずほ ぼ一定であることから，濃度変化をコントロールしてい る亀裂は比較的深いところにあると推定される.

このモデルによれば, 歪み計の $0 \mathrm{~m}-30 \mathrm{~m}$ 間, $30 \mathrm{~m}-$ $70 \mathrm{~m}$ 間に対応する区域 (Fig. 9 中の A 地域) では, 炭酸 ガス濃度も逆の变化をしなければならない。しかし，炭 酸ガス濃度測定点の中でそのようなところはなく，全て の測定值はSTNS70-100 の伸張に伴って增加してお り, 減少している測定点はない，これについては，その ような場所にガスの採取点がなかったと解釈するしかな いが, 今後の課題である.

炭酸ガス濃度変化とSTNS70-100 との間に最も高い 正の相関が観測されたのは測定点 27 のデータである. 相関係数は 0.73 であった (なお, タイムラグを考慮して ピーク時をあわせると 0.76 となる). 測定点 27 のデー 夕と歪みデータとをグラフにしたのが Fig. 10 である. 直線は最小二乗法による回帰直線であり, $y=15 x+480$ である.ここで $y$ は, 測定点 27 の $\mathrm{CO}_{2}$ 濃度 (単位 ppm) で, $x$ はSTNS70-100 (単位 10-8) である.

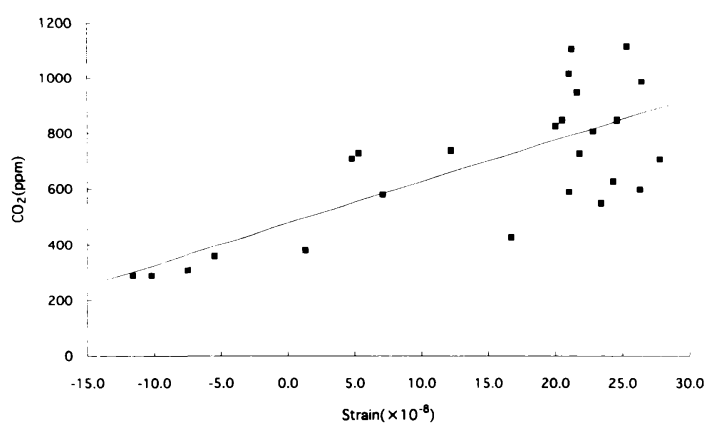

Fig. 10. Correlation between STNS70-100 and $\mathrm{CO}_{2}$ concentration at the measurement point of No. 27.

\section{§5. まとめ}

地中ガスの挙動と地殻変動との関係を見るために, 土 壤ガス中の炭酸ガス濃度の変動を観測してきた. 今回の 観測で, 従来言われてきたように，断層直上付近で炭酸 ガス濃度が大気中に比べ高いことが確認されたと同時 に, 炭酸ガス濃度は, 長野市松代地域の広い範囲にわ たって地震観測室大坑道内で観測されていた局所的な南 北歪みに対応して变化する傾向のあることが分かった。

地震観測室大坑道内の 12 測点における炭酸ガス濃度 変動を説明する一つのモデルを提案した，長野市松代地 域の地下には豊富な炭酸ガス源があり, 常時ガスは放出 されているとする考えのあとで, 坑道内の地下に存在し ていた降雨により膨張しやすい東西走向に近い割れ目群 の膨張が, 周囲の割れ目を開口させることで, 炭酸ガス の湧出量が増加していたとするモデルである. なお, 歪 み変化の計測デー夕がないため, 玉依比売命神社と牧内 地区における炭酸ガスの湧出機構が坑道内と同じものか ぞうかは確定できない。

\section{謝辞}

この研究にあたり, 気象庁地震観測室の職員の方々に ご協力を頂いた. また, 竹内益美氏は, 観測装置を設置 する土地を快く貸してくださった，当時信州大学理学部 地質学科大学院生奥沢 保氏, 四回生新井崇史氏, 海野 真秀氏には野外における調查を手伝って頂いた。匿名の 方から頂いた査読コメントはデータを解釈する上で非常 に役立った．以上の方々に，厚く感謝の意を表します。

\section{文献}

松田時彦, 1967, 松代地震断層の地質学的性質, 地震研 彙報, 45, 537-550.

森本良平・村井 勇・松田時彦・中村一明・恒石幸正 吉田鎮男, 1966, 松代群発地震地域とその周辺地方の 地質, 地震研彙報, 44, 423-445.

村井 勇, 1967, 松代群発地震地域のわれめ系解析, 地 震研彙報, 45, 505-536.

永田松三・伊藤司郎, 1969, 松代地震地域における地化 学探查 (続報), 防災科学技術総合研究報告, 18, 2939.

南雲昭三郎 - 高橋 博 - 長谷川 淳, 1967, 気象庁地震 観測所坑内における弾性波速度測定, 防災科学技術総 合研究速報, 5, 49-55.

中村一明, 1971, 松代地震から学んだこと, 科学朝日, 1971 年 10 月号, 127-133.

西前裕司・涌井仙一郎，1996，松代における伸縮計およ び水管傾斜計に現れた降雨の影響とそのシミュレー ション, 気象庁精密地震観測室技術報告, 13, 17-27.

Tsuneishi, Y. and K. Nakamura, 1970, Faulting associated with the Matsushiro swarm earthquakes, Bull. Earthq. Res. Inst., 48, 29-51. 